TEME, г. XLV, бр. 1, јануар - март 2021, стр. 281-298

\begin{tabular}{lr}
\hline Оригинални научни рад & https://doi.org/10.22190/TEME200130015I \\
Примљено: 30.1.2020. & UDK 159.942:004.738.5
\end{tabular}

Ревидирана верзија: 6. 12. 2020.

Одобрено за штампу: 26. 2. 2021.

\title{
RELATIONSHIP BETWEEN FACEBOOK-RELATED BEHAVIORS AND CHARACTERISTICS OF A ROMANTIC RELATIONSHIP
}

\author{
Ivana Isailović, Jelena Šakotić-Kurbalija* \\ University of Novi Sad, Faculty of Philosophy, Novi Sad, Serbia
}

\begin{abstract}
The problem of this study was to explore the relationship between Facebookrelated behaviors and characteristics of romantic relationships. Based on the results of previous research, we assumed that there would be significant gender differences in the frequency and manner of using Facebook, that there would be a significant relationship between the attachment style and Facebook monitoring and Facebookrelated conflicts, and that Facebook monitoring and Facebook-related conflicts would significantly predict relationship quality. The sample consisted of 201 respondents from Serbia, $42.5 \%$ of which were male. Using the Dyadic adjustment scale - DAS (Spanier, 1976, 1989), Interpersonal electronic surveillance - IES (Tokunaga, 2011; modification Tucker, 2014), The Facebook-related Conflict Scale (Clayton, Nagurney, \& Smith, 2013) and Experiences in Close Relationships Inventory - ECR (Brennan, Clark, \& Shaver, 1998; modification Kamenov \& Jelic, 2003), results showed that women use Facebook and post the relationship status and pictures with a partner more often than men and that people with an insecure attachment style more often engage in Facebook monitoring. Also, results showed that Facebook-related conflicts are a significant predictor of relationship quality. The present study contributes to the understanding of romantic relationship dynamics in the age of social networking sites, by pointing to the relational factors that are potentially at risk because of Facebook use.
\end{abstract}

Key words: Social networking sites, Romantic relationships, Attachment, Conflicts, Electronic surveillance.

\section{ПОВЕЗАНОСТ ПОНАШАЫА НА ФЕЈСБУКУ И КАРАКТЕРИСТИКА ПАРТНЕРСКОГ ОДНОСА}

\section{Апстракт}

Проблем овог истраживања био је да испита повезаност између понашања везаних за употребу Фејсбука и карактеристика партнерског односа. На основу

\footnotetext{
* Аутор за кореспонденцију: Јелена Шакотић-Курбалија, Универзитет у Новом Саду, Филозофски факултет, Др Зорана Ђинђића 2, 21102 Нови Сад, Србија, jelenasakotickurbalija@ff.uns.ac.rs
} 
резултата досадашњих истраживања, претпоставили смо постојање значајних полних разлика у учесталости и начину коришћења Фејсбука, као и постојање значајне повезаности стила афективне везаности, надзирања партнеровог понашања на Фејсбуку и конфликата везаних за употребу Фејсбука. Такође, претпоставили смо да су степен надзирања партнерових активности на Фејсбуку и конфликти везани за употребу Фејсбука значајни показатељи квалитета везе. На узорку од 201 испитаника из Србије, од којих је 42,5\% мушког пола, примењене су Скала дијадне прилагођености (Dyadic adjustment scale - DAS; Spanier, 1976, 1989), Скала електронског надзирања (Interpersonal electronic surveillance - IES; Tokunaga, 2011; модификација: Tucker, 2014), Скала конфликата везаних за Фејсбук (The Facebook-related Conflict Scale; Clayton, Nagurney, \& Smith, 2013) и Инвентар искустава у блиским односима (Experiences in Close Relationships Inventory - ECR; Brennan, Clark, \& Shaver, 1998; модификација: Kamenov \& Jelić, 2003). Резултати показују да жене чешће користе Фејсбук, објављују свој статус везе и фотографије са својим партнером у односу на мушкарце и да несигурно везане особе чешће надзиру понашање свога партнера на Фејсбуку. Поред тога, резултати показују и то да су конфликти везани за Фејсбук значајан показатељ квалитета везе. Резултати истраживања доприносе бољем разумевању динамике романтичних односа у савременом тренутку употребе друштвених мрежа, указујући притом на могуће ризике употребе Фејсбука.

Кључне речи: друштвене мреже, романтичне везе, афективна везаност, конфликти, електронско надзирање.

\section{INTRODUCTION}

Romantic relationship quality is a construct that stems from the "marital quality" construct (Lewis \& Spanier, 1979) and represents the subjective evaluation of a romantic couple's relationship on a number of dimensions and evaluations (Spanier \& Lewis 1980, p. 826). Relationship quality is positively associated with good adjustment, adequate communication, a high level of relationship happiness, integration, and a high degree of relationship satisfaction (Lewis \& Spanier 1979, p. 269). Recent research of relationship quality has tended to focus on interpersonal factors, such as interactions between partners, or intrapersonal factors, such as personality traits and attachment styles (Watson, Hubbard \& Wiese, 2000), and has emphasized the importance of communication between partners for the growth and development of relationships (e.g. Sternberg, 1986; Meeks, Hendrick \& Hendrick, 1998). Research show that good communication strategies between partners represent a significant predictor of relationship satisfaction (Overall, Fletcher, Simpson, \& Sibley, 2009). Couples with good communication strategies have benefits in terms of maintaining relationship quality, while couples with poorer communication strategies have a perception of greater investment in the relationship, less success in the relationship and more conflict (Christensen \& Shenk, 1991; Egeci \& Gencoz, 2011). Research has shown that in recent times, communication among romantic couples most often takes place through social networking sites (Kalpidou, Costin, \& Morris, 2011). 
Social networking sites changed the landscape for interpersonal communication, especially in the area of romantic relationships (Rus \& Tiemensma, 2017). In a survey conducted by Hall (2014), it was estimated that $35 \%$ of all couples who have entered into a marriage between 2005 and 2012, started their relationship through these sites. It has also been shown that social networking sites play a significant role in all stages of romantic relationships, including initiation, escalation, maintenance, dissolution, and even monitoring partner's behavior after the breakup (Smith \& Duggan, 2013).

\section{Social Networking Sites}

Social Networking Sites (SNS) represent a social community organized in a virtual world. Connecting with people on social networking sites does not require immediate physical surrounding. These sites enable the creation of a public or semi-public profile, whereby users can become "friends" with other users of these sites. The basic idea of constructing the SNS was to create the ability to connect people who know each other in the real world through the Internet, which would facilitate their communication (Boyd, 2008).

Social network users usually represent themselves with real names, which are often accompanied by their picture. In other words, the user profile represents a personal representation on the Internet (Boyd, 2008). It is considered that SNS are a valuable method of maintaining friendships (Ellison, 2007). SNS are the main medium for communication and the establishment and maintenance of interpersonal relations (Boyd, 2008; Turkle, 2011). Research has shown that Facebook is the most used social networking site, with over two billion active users around the world, on a monthly basis, including 74\% of young people aged 12 to 24 in the United States (Boyd, 2008; Kalpidou, Costin, \& Morris, 2011). Although there has recently been an expansion in the use of other social networking sites, Facebook still has 25\% more users than Twitter, and $50 \%$ more than Instagram. It has been shown that almost half of Facebook users visit this social network at least six times a week and that US residents spend more time on Facebook than on any other website (Nielsen, 2011).

Facebook is a social network with different options. On Facebook, it is possible to post statuses, different pictures on personal or other people's profiles, to comment on statuses and/or pictures of other people, post personal biography, etc. Due to a large amount of personal information that users post on this social network, Facebook has become one of the most interesting topics for researchers. Most research conducted on Facebook focused on friendships, networking, online/offline communication and privacy issues (Boyd, 2008). However, when Facebook introduced the possibility to share information on relationships with online friends 
and emotional partners, and merge profiles based on these characteristics, researchers in the field of psychology of intimate relationships raised the question of how characteristics and functions of Facebook are associated with the characteristics of a romantic relationship.

In this paper, we will try to include the existing theories in the field of intimate relations to explore how social network use between partners is related to relationship quality. We will dedicate special attention to previous research on predictors of relationship quality in the context of the use of social networking sites (e.g. Muise, Christofides, \& Desmarais, 2009; Joinson, 2008).

\section{Theoretical Approaches and Previous Research on the Relationship of the SNS Use and the Characteristics of a Romantic Relationship}

In the available literature, there is no unique theoretical framework for studying the relationship between the use of SNS and the characteristics of a romantic relationship (Rus \& Tiemensma, 2017). Theories in this field are still developing, and research involves different constructs. Rus and Tiemensma (2017) state that the theories in the field of romantic relationships that are most often associated with the characteristics of romantic relationships in the era of social networking sites are Theory of Interdependence (Thibaut \& Kelley, 1959), the Structural interdependence theory (Milardo, 1986; Surra, 1988) and The Attachment Theory (Bowlby, 1973).

According to the Interdependence Theory (Thibaut \& Kelley, 1959), the development, growth and eventual resolution of close relationships are a consequence of social exchange, more precisely, the exchange of benefits and losses between the partners and between partners and others. The central construct of this theory is the "level of dependency" which implies the degree to which an individual needs a relationship or a measure in which an individual relies on a relationship to meet the desired expectations. According to this theory, a person's satisfaction with a romantic relationship can be assessed if the expectations from the relationship are known. If the expectation level exceeds benefits, a person will be dissatisfied, or otherwise. It is important to note that the level of expectation of relationships relies on the experience of past relationships, so a person who has had unsatisfactory relationships in the past can be satisfied with a small benefit from the current relationship, while for a person who in the past had satisfactory relationships even a high gain from the current relations can be inadequate (Tadinac, Kamenov, Jelic, \& Hromatko, 2007).

Closely related to the Interdependence Theory is the Structural interdependence theory, which refers to the connection between couple's social network and dyadic adjustment (e.g., Milardo, 1986; Surra, 1988). The term dyadic adjustment is used to describe the experience of couples 
acclimating to a relationship (Spanier, 1976). Dimensions used to determine levels of dyadic adjustment include relationship satisfaction, cohesion, agreement, affection, and conflict (Spanier, 1976). Relationship satisfaction represents partner's subjective evaluation of the relationship, and, therefore, is distinct for each partner. Cohesion describes commitment to the relationship and companionship received from the relationship. Agreement on important issues is also vital to well-adjusted relationships. These relationships are characterized by affection and calm resolution of conflict (Kendrick \& Drentea, 2016). The Structural interdependence theory suggests that as a couple becomes more involved and interdependent, they develop increasingly interdependent networks. The pattern of ties in the couple's social networks influences the flow of resources that affect the potential for the couple's dyadic adjustment (Kearns \& Leonard, 2004).

Considering the fact that the development, growth and eventual disintegration of close relationships are a consequence of social interactions, and that a good deal of interactions among partners is taking place online today, it seems important to apply the principles of these theories to virtual interactions. According to both the Interdependence Theory and the Structural interdependence theory, an individual will be more dissatisfied with a relationship if he reports more negative than positive online interactions with a partner (Clayton, Nagurney, \& Smith, 2013). Also, in line with the basic principles of both theories it is assumed that if one or both partners feel that they do not get enough support and get a lot of criticism for online behavior, they will be less satisfied with the relationship, due to an excessive imbalance in benefits and losses within the relationship. In other words, a person will be dissatisfied with a relationship if their partner does not post or even refuses to post a relationship status or a picture, exchanges messages with the opposite sex, etc. Although research has not yet examined the ways in which romantic partners use relationship status, preliminary studies have shown that publicly disclosing the single status is a reliable and effective method for making contact with potential romantic partners (Young, Dutta, \& Dommety, 2009). In accordance with the Theory of Interdependence, it is possible that the "single" status gives the opportunity for a person to find more desirable alternatives, which causes the partner's dissatisfaction with the relationship. Using this theory, Fox and Warber (2013) examined adult experiences with Facebook, focusing primarily on relationship status. The results of this study have shown that posting the relationship status is related to a greater sense of commitment and intensity of closeness among partners. Gender differences in the perception of the significance of this status were identified, with women more perceiving that this status conveys commitment and intensity of closeness. Additionally, the results of this study have shown that setting up a profile picture in which a person and their 
emotional partner are shown together and posting messages involving an emotional partner is associated with greater intimacy. This kind of Facebook use indicates how much people care about their partner and how serious a romantic relationship is (Papp, Danielewicz, \& Cayemberg, 2012).

The Attachment Theory assumes that, in relation to securely attached persons, persons with insecure attachment styles tend to experience lower levels of trust, satisfaction, intimacy, and stability in their romantic relationships (Kirkpatrick \& Davis, 1994). They are also prone to jealousy (Buunk, 1997). People with insecure attachment tend to be suspicious and worry that their partner will leave them (Guerrero, 1998), which increases the monitoring of partner behavior for the purpose of searching for signs of declining interest. For these reasons, partners with insecure attachment often use social networking sites to monitor their partner's activities and often, each sign of communication of their partner with the opposite sex is perceived as a threat to a relationship. On the other hand, people with a secure attachment rarely resort to these behaviors and use Facebook for other purposes, such as communicating with other people, browsing interesting content, and the like.

Using the Attachment Theory, Emery, Muise, Dix, \& Le (2014) have pointed out the existence of a relationship between attachment style and behavioral and emotional responses to behavior on social networking sites. According to the results of this research, people with insecure attachment show behavior that indicates the desired closeness and fear of abandonment, such as the high visibility of a romantic relationship on social networking sites. Researchers consistently point out that people with a preoccupied attachment often monitor partner's behavior on social networking sites more closely (Fox \& Warber, 2013; Marshall, Bejanyan, Di Castro, \& Lee, 2013; Muise, Christofides, \& Desmarais, 2014). Applying the Attachment Theory in the context of the use of social networking sites suggests that the adult attachment style motivates offline romantic behavior (Collins \& Allard, 2001) and can also transfer into the online behavior of romantic partners (Rus \& Tiemensma, 2017).

In general, the results of studies of the relationship between Facebook use and the characteristics of the romantic relationship are inconsistent. Certain research (eg. Kujath, 2011) pointed to a positive relationship between the use of social networks and growth and the development of partner relationships. Also, research showed that virtual communication among partners increases the likelihood of communication in the real world (Ledbetter et al., 2011) and it is in a positive relationship with the perception of the relationship quality (McGlynn, 2006, according to Carpenter \& Spottswood, 2013).

On the other hand, more research suggests that the insight into a partner's past through Facebook can cause a variety of feelings, such as envy, jealousy, and conflicts in relationships, which may be associated 
with a reduction in the level of satisfaction and security in a partner relationship (Papp, Danielewicz, \& Cayemberg, 2012). Studies show that compulsive Facebook use is associated with more conflicts among partners, the experience of exclusion and concealment, as well as perception of less commitment, passion, and intimacy (Billedo, Kerkhof, \& Finkenauer, 2015). Clayton, Nagurney and Smith (2013) found that Facebook-related conflict is associated with negative relationship outcomes. Additional research has found that monitoring partner's Facebook activities increase the probability of engaging in other obsessive behaviors (Fox \& Warber, 2013; Fox, Warber, \& Makstaller, 2013). It has also been shown that the use of the Internet for the purpose of monitoring a partner's behavior is negatively related to the relationship quality, and relationship certainty (Tokunaga, 2011).

\section{Research Goals and Hypothesis}

Considering the inconsistency of previous research results, the first goal of this study is to provide a more detailed insight into the relationship between Facebook use and relationship characteristics, using the Interdependence Theory and the Attachment Theory as theoretical frameworks. Based on the results of previous studies that state that women are more likely to use social networking sites, post pictures with a romantic partner, and the relationship status (Park, Kee, \& Valenzuela, 2009), we propose the following:

H1: Women use Facebook and post the relationship status and pictures with a partner more often than men.

H2: More frequent use of Facebook is related to lower relationship quality.

H3: There is a significant relationship between the use of Facebook and the attachment style. Persons with an insecure attachment style more often post the relationship status and pictures with a partner than persons with a secure attachment style.

The second goal of this study is to examine the relationship between attachment style and Facebook-related behaviors. As mentioned earlier, people with an insecure attachment tend to feel lower levels of trust, satisfaction, intimacy, and stability in their romantic relationships (Kirkpatrick \& Davis, 1994). They also tend to be suspicious and worried that their partner will leave them (Guerrero, 1998). For these reasons, they often use social networking sites to track monitor partners' activities. Results of previous research also showed that conflicts related to Facebook use were associated with lower relationship satisfaction (Papp, Danielewicz, \& Cayemberg, 2012). Following the above-mentioned research, we propose:

H4: There is a significant relationship between the attachment style, conflicts over Facebook use Facebook monitoring. Men and women 
with insecure attachment styles are more often involved in Facebook monitoring and have more conflicts over Facebook use than men and women with a secure attachment style.

The last goal of this study is to examine the contribution of conflicts over Facebook use and Facebook monitoring to the prediction of the relationship quality, relative to the attachment style. Based on the previous research (Papp, Danielewicz, \& Cayemberg, 2012), we expect that:

H5: Among persons with insecure attachment, Facebook monitoring and conflicts over Facebook use significantly predict the relationship quality. However, among persons with secure attachment styles, only conflicts over Facebook use significantly predict the relationship quality.

\section{METHOD}

\section{Sample and Procedure}

In the present study, we used a convenience sampling method. Data was collected using the CAWI (Computer-Assisted Web Interviewing) technique. Participation was anonymous and voluntary. The study included only participants older than 18 years of age, who were not married/cohabitating nor with children and who were in a current romantic relationship for a minimum of 6 months. After excluding missing data and participants who did not meet the inclusion criteria, the sample amounted to 201 respondents $42.5 \%$ of whom were male. The average age of the participants was 28.26 years $(\mathrm{SD}=5.56$; $\mathrm{Min}=19$ years old, Max $=54$ years old), with no statistically significant gender differences in age $(\mathrm{t}(199)=-1.24, \mathrm{p}>.05)$. The average relationship length was 42.93 months ( $\mathrm{SD}=40.15$; Min= 6 months, Max $=22$ years). There were significant gender differences in the relationship length $(\mathrm{t}(199)=-4.29, \mathrm{p}<.01)$, with women having longer relationships $\left(\mathrm{M}_{\text {women }}=54.41, \mathrm{SD}_{\text {women }}=47.52\right.$; $\left.\mathrm{M}_{\text {men }}=31.10, \mathrm{SD}_{\text {men }}=26.17\right)$. Participants also provided information on the place of living, with the most participants living in a city (51.5\%), and employment, with the most participants being employed (70.9\%). It is important to state that there was a significant relationship between the relationship length and conflicts over Facebook use $(r=-.22, p<.01)$. There were no significant correlations between relationship length and Facebook monitoring $(r=-13, p>.05)$, or between the relationship length and the relationship quality $(r=.14, \mathrm{p}>.05)$.

\section{Measures}

Facebook Use scale was designed for this research. Within this scale, respondents were asked questions related to daily Facebook visits and the frequency of weekly Facebook usage. In addition to these questions, the respondents were asked to respond to two questions concerning 
the status of their relationship on Facebook: 1. "Is your relationship status posted on Facebook, 2. If the answer to the previous question is affirmative, is your relationship status with your partner displayed on Facebook in a way that your profiles are linked? Also, the respondents were asked to answer the question "Do you, as a profile picture, post a picture in which you and your partner are shown together?", with possible answers: 1. "Yes, I always post profile picture on which partner and I are together, 2. "Sometimes I put something else, but I often post a profile picture on which partner and I are together." 3. "I rarely post a profile picture on which partner and I are together"; and 4. "I never post a profile picture on which partner and I are together."

Dyadic adjustment scale (DAS, Spanier, 1976, 1989) was used for measuring relationship quality. The scale has 32 items, organized into four subscales, including dyadic satisfaction $(n=10)$, cohesion $(n=5)$, consensus $(n=13)$, and affectional expression $(n=4)$.

Because the DAS was originally designed to measure the relationship quality between married or cohabitating couples, according to Hand, Thomas, Buboltz, Deemer, \& Buyanjargal (2013) for this research one question was changed from "Do you ever regret that you married or lived together?" to "Do you ever regret getting into a relationship with your partner?', The reliability of this scale was .88 .

Interpersonal electronic surveillance (IES, Tokunaga, 2011), a modified version (Tucker, 2014), was used to measure Facebook monitoring. The original scale refers to the usage of all social networking sites, while in the modified version, the items refer exclusively to Facebook. Like the original, the modified scale consists of 12 items measured on a 7-point Likert scale from 1 - strongly disagree to 7 - strongly agree. Statements include visiting partner's Facebook page often, looking through partner's Facebook pictures, noticing when partner updates his/her Facebook page, trying to monitor partner's behaviors through his/her Facebook page, etc. Higher scores reflect higher usage of Facebook for surveillance. Two professional translators, with knowledge of education and psychology, worked independently, and then they compared their translations to identify any variance in translation, in order to assess equivalence. Cronbach's alpha for this scale was .82.

The Facebook-related Conflict Scale (Clayton, Nagurney, \& Smith, 2013) is a six-item questionnaire used to measure how Facebook use may increase complications in an intimate relationship. Items include arguments over commenting friends' profiles, reconnecting with individuals with whom respondents have had past romantic relationships, etc. As for the previous scale, two independent translators compared their translations to identify any variance in translation, in order to assess equivalence. The Cronbach's $\alpha$ for the scale in the present study was .95 . 
Experiences in Close Relationships Inventory (ECR, Brennan, Clark, \& Shaver, 1998; modification Kamenov \& Jelic, 2003). To identify partners' attachment styles we used a shortened version of the scale of 18 items (Kamenov \& Jelic, 2003). The instrument consists of the anxiety $(\alpha=.71)$ and the avoidance subscale $(\alpha=.78)$. By combining the scores on the specified subscales, it is possible to identify four types of attachment: 1. Secure (low scores on both dimensions); 2. Avoiding / rejecting (low scores on the anxiety, and high scores on the avoidance subscale); 3. Preoccupied (high score on the anxiety, and low on the avoidance subscale), and 4. Fearful (high scores on both dimensions). The Cronbach's $\alpha$ for the scale in the present study was .79 .

\section{RESULTS}

Means, standard deviations, skewness, and kurtosis of all subscales of DAS, IES, Conflict Scale, and ECR are presented in Table 1. Based on a milder criterion (values between -2 and 2, Finney \& DiStefano, 2006), the values of skewness and kurtosis were acceptable for all subscales of all questionnaires, indicating that data distribution does not significantly deviate from normal.

Table 1. Descriptive indicators for DAS, IES, Conflict Scale, and ECR

\begin{tabular}{lrlrrrrr}
\hline & \multicolumn{1}{c}{ Min } & Max & \multicolumn{1}{c}{ M } & \multicolumn{1}{c}{ SD } & $\alpha$ & Skewness & Kurtosis \\
\hline Conflict & 6.00 & 25.00 & 12.57 & 6.61 & .95 & .60 & -1.20 \\
IES & 12.00 & 54.00 & 30.50 & 9.11 & .82 & -.14 & -.55 \\
Anxiety & 9.00 & 48.00 & 19.64 & 7.63 & .71 & 1.26 & 1.65 \\
Avoidance & 9.00 & 46.00 & 23.59 & 9.99 & .78 & .24 & -1.27 \\
Relationship quality & 68.00 & 139.00 & 112.04 & 14.37 & .88 & -.78 & -.09 \\
\hline
\end{tabular}

Based on the previous results, the first goal of this study was to examine the relationship between Facebook use and relationship characteristics. For the first hypothesis, we expected that women use Facebook and post the relationship status and pictures with a partner more often than men. Results showed that there were significant gender differences in $\mathrm{Fa}$ cebook use, with large effect size and posting pictures with a partner, with moderate effect size. Women use Facebook more often than men $\left(\mathrm{M}_{\mathrm{women}}=6.83, \mathrm{SD}_{\mathrm{women}}=3.15 ; \mathrm{M}_{\mathrm{men}}=3.71, \mathrm{SD}_{\text {insecure }}=2.63\right)$ and post pictures with their partner more often than men. There were no significant gender differences in posting relationship status. Also, there were no significant differences in posting relationship status and pictures with a partner between persons with secure and insecure attachment style (Table 2). The hypothesis that more frequent use of Facebook is related to lower relationship quality was not confirmed $(\mathrm{r}=.12, \mathrm{p}>.05)$. 
Table 2. Gender and attachment style differences in Facebook use, posting pictures with partner and relationship status

\begin{tabular}{llcc}
\hline Gender differences & df & t & Cohen's d \\
\hline Facebook use & 199 & $-7.61^{*}$ & 1.07 \\
\cline { 2 - 4 } & df & $\chi^{2}$ & Cramer's V \\
\cline { 2 - 4 } Posting pictures with a partner & 3 & $7.87^{*}$ & .20 \\
Posting relationship status & 1 & .58 & .05 \\
\hline Differences between secure and insecure attachment style & df & $\chi^{2}$ & Cramer's V \\
\hline Posting relationship status & 1 & 2.13 & .10 \\
Posting pictures with a partner & 3 & 1.51 & .08 \\
\hline
\end{tabular}

The second goal of this study was to examine the relationship between attachment style and Facebook-related behaviors. We expected that men and women with insecure attachment styles more often involve in Facebook monitoring and have more conflicts over Facebook use than men and women with a secure attachment style. Using criteria for the classification of attachment style by Brenan, Clark, \& Shaver (1995), in this research, there were $64.7 \%$ of persons with secure and $35.3 \%$ of persons with insecure attachment style. Results showed that there were significant differences between persons with secure and insecure attachment style in Facebook monitoring, with persons with insecure attachment style engaging in Facebook monitoring more often $\left(M_{\text {secure }}=29.52\right.$, $\mathrm{SD}_{\text {secure }}=9.04 ; \mathrm{M}_{\text {insecure }}=32.30, \mathrm{SD}_{\text {insecure }}=9.02$ ). It is important to note that effect size can be considered as small. There were no significant differences between persons with secure and insecure attachment in conflicts over Facebook use (Table 3).

Table 3. Differences between attachment styles in Facebook monitoring and conflicts over Facebook use.

\begin{tabular}{lccc}
\hline Differences between attachment styles & df & t & Cohen's d \\
\hline Facebook monitoring & 199 & $-2.09^{*}$ & .30 \\
Conflicts over Facebook use & 199 & -1.13 & .16 \\
\hline
\end{tabular}

The last goal of this study was to examine the contribution of conflicts over Facebook use and Facebook monitoring to the prediction of the relationship quality, relative to the attachment style. Based on the previous research (Papp, Danielewicz, \& Cayemberg, 2012), we expected that among persons with insecure attachment, Facebook monitoring and conflicts over Facebook use significantly predict the relationship quality, while among persons with secure attachment styles, only conflicts over Facebook use significantly predict the relationship quality. Intercorrelations of variables of conflict over Facebook use, IES, Anxiety, Avoid- 
ance, and relationship quality are presented in Table 4 . For the last hypothesis, we used the regression analysis for participants with secure and insecure attachment style separately. Results showed that in both attachment styles, only conflicts over Facebook use significantly predict relationship quality (see Table 5). It is important to note that, among participants with an insecure attachment style, the model explained $37 \%$ of the variance, while among participants with insecure attachment style, and the model explained $36 \%$ of the variance.

Table 4. Intercorrelations of variables of conflict over Facebook use, IES, Anxiety, Avoidance, and relationship quality

\begin{tabular}{llllll}
\hline & 1. & 2. & 3. & 4. & 5. \\
\hline 1. Conflict & -- & $.64^{* *}$ & $.38^{* *}$ & $.66^{* *}$ & $-.61^{* *}$ \\
2. IES & $.53^{* *}$ & -- & $.44^{* *}$ & $.35^{* *}$ & $-.44^{* *}$ \\
3. Anxiety & .13 & $.39^{* *}$ & -- & $.43^{* *}$ & $-.37^{* *}$ \\
4. Avoidance & .02 & -.21 & $-.74^{* *}$ & -- & $-.49^{* *}$ \\
5. Relationship quality & $-.59^{* *}$ & -.20 & -.20 & .10 & -- \\
\hline
\end{tabular}

Note: correlations for persons with a secure attachment style are presented above the diagonal, and correlations for persons with an insecure attachment style are presented below the diagonal ${ }^{* *} \mathrm{p}<.001$

Table 5. Regression analysis: Prediction of relationship quality based on Facebook monitoring and Facebook-related conflicts

\begin{tabular}{lcccc}
\hline \multicolumn{1}{c}{ Predictors } & \multicolumn{2}{c}{ Secure attachment style } & \multicolumn{2}{c}{ Insecure attachment style } \\
& $\beta$ & $\mathrm{t}$ & $\beta$ & $\mathrm{t}$ \\
\hline Facebook monitoring & -.09 & -.98 & .16 & 1.37 \\
Facebook-related conflicts & $-.55^{* *}$ & -6.03 & $-.67^{* *}$ & -5.86 \\
\hline & $\mathrm{T}(2,127)=37.998, \mathrm{p}<.001$ & $\mathrm{~F}(2,68)=19.302, \mathrm{p}<.001$ \\
\hline
\end{tabular}

\section{DISCUSSION}

The research was conducted to determine the relationship between the use of social networking sites and the quality of the romantic relationship. Based on the results of previous research (Park, Kee, \& Valenzuela, 2009; Papp, Danielewicz, \& Cayemberg, 2012), we assumed that there would be significant gender differences in the frequency and manner of using Facebook and its features, that there would be a significant role of attachment style in the degree of Facebook monitoring and Facebookrelated conflicts, and that Facebook monitoring and Facebook-related conflicts will significantly predict relationship quality.

The results confirmed the assumption of this research that women use Facebook and post the relationship status and pictures with a partner more often than men. These results are consistent with the results of previous studies (Park, Kee, \& Valenzuela, 2009). However, it was not con- 
firmed that more frequent use of Facebook is related to lower relationship quality and that people with an insecure attachment style more often post the relationship status and pictures with a partner than people with a secure attachment style. These results are inconsistent with the results of previous studies suggesting that people with insecure attachment on social networking sites show behavior that indicates the desired closeness and fear of abandonment, such as the high visibility of a romantic relationship closely (Fox \& Warber, 2013; Marshall et al., 2013; Muise, Christofides, \& Desmarais, 2014). The obtained results can be explained from the methodological point. Namely, the sample in the research consisted of individuals, and not couples. It is possible that these differences exist within a romantic relationship, and that the use of Facebook features in the context of romantic relationships is influenced by a combination of partner attachment styles, rather than by the attachment style of individuals. Future research should include couples and use a dyadic analysis to provide a more detailed insight into this relationship.

The results of this study have confirmed the assumption that there are significant differences in the level of Facebook monitoring between people with secure and insecure attachment style. People with insecure attachment style engage in Facebook monitoring more often. The results of the previous research consistently pointed out that people with insecure attachment often monitor the behavior of the partner on social networking sites (Fox \& Warber, 2013; Marshall et al., 2013; Muise, Christofides \& Desmarais, 2014). However, this research did not include the reasons for the partner's monitoring among people with insecure attachment styles. Future research should address the question of whether people with insecure attachments styles engage in Facebook monitoring to search for signs of declining interest, or there is another explanation. Within the second goal, the results did not confirm the assumption that there are significant differences in conflicts over Facebook use between people with secure and insecure attachment style. As for the previous hypothesis, these results could be explained with the fact that this research did not include couples.

The last hypothesis of this research was that there would be a significant link between Facebook-related conflicts, Facebook monitoring and relationship quality, regarding attachment style. More precisely, it was expected that among people with insecure attachments, Facebook monitoring and conflicts over Facebook use significantly predict the relationship quality, while among people with secure style attachments, only conflicts over Facebook use significantly predict the quality of a relationship. The results showed that the model was statistically significant, with only Facebook-related conflicts as a significant predictor of relationship quality in both participants with a secure and insecure attachment style. 
These results are consistent with previous research indicating that Facebook-related conflicts are associated with lower relationship satisfaction (Papp, Danielewicz, \& Cayemberg, 2012) and quality (Clayton, Nagurney, \& Smith, 2013). It is possible that Facebook-related conflicts actually occur among partners who are experiencing potential uncertainty regarding the stability or future of their relationship, so future research should address this issue and include relationship stability and certainty as mediating variables.

It is important to note that this research has certain methodological issues. One of the methodological issues is the convenient sample, which raises the question of the possibility of generalizing the findings to the population in our country. Future research should involve couples to examine whether similar findings are obtained in this case. It would be desirable to organize longitudinal research to monitor the frequency of these behaviors and their relationship with the relationship quality in different stages of the relationship. Also, one of the issues in this study is the fact that age and the length of relationships were not controlled in this study. More precisely, even though this study included respondents with minimum age of 18 who were in a current relationship for minimum 6 months, there was no upper limit in age or relationship length, which could affect the results. Future research should control these variables or examine their mediation effect on the relationship between Facebookrelated behaviors and the characteristics of a romantic relationship.

Nevertheless, this research is one of the first research in Serbia that provides an insight into the connection between the use of Facebook and its characteristics with the quality of the romantic relationship. On a practical note, the present study contributes to the understanding of romantic relationships dynamics in the age of social networking sites, by pointing to the relational factors that are potentially at risk because of Facebook use. Knowing these factors can help us develop relevant couple therapy or interventional techniques for maintaining a healthy romantic relationship.

\section{REFERENCES}

Billedo, C. J., Kerkhof, P., \& Finkenauer, C. (2015). The use of social networking sites for relationship maintenance in long-distance and geographically close romantic relationships. Cyberpsychology, Behavior, and Social Networking, 18(3), 152-157. doi: 10.1089/cyber.2014.0469

Bowlby, J. (1973). Attachment and loss, vol. II: Separation. Basic Books.

Boyd, D. (2008). Can social network sites enable political action. International Journal of Media and Cultural Politics, 4(2), 241-244. doi: 10.1386/macp.4.2.241_3

Brennan, K. A., Clark, C. L., \& Shaver, P. R. (1998). Self-report measurement of adult romantic attachment: An integrative overview. In J. A. Simpson \& W. S. Rholes (Eds.), Attachment theory and close relationships (pp. 46-76). New York: Guilford Press. 
Buunk, B. P. (1997). Personality, birth order and attachment styles as related to various types of jealousy. Personality and Individual Differences, 23(6), 9971006. doi: 10.1016/S0191-8869(97)00136-0

Carpenter, C. J., \& Spottswood, E. L. (2013). Exploring romantic relationships on social networking sites using the self-expansion model. Computers in Human Behavior, 29(4), 1531-1537. doi: 10.1016/j.chb.2013.01.021

Christensen, A., \& Shenk, J. L. (1991). Communication, conflict, and psychological distance in nondistressed, clinic, and divorcing couples. Journal of consulting and clinical psychology, 59(3), 458.

Clayton, R. B., Nagurney, A., \& Smith, J. R. (2013). Cheating, breakup, and divorce: Is Facebook use to blame?. Cyberpsychology, Behavior, and Social Networking, 16(10), 717-720. doi: 10.1089/cyber.2012.0424

Collins, N. L., \& Allard, L. M. (2001). Cognitive representations of attachment: The content and function of working models. Blackwell handbook of social psychology: Interpersonal processes, 2, 60-85. doi: 10.1002/9780470998557.ch3

Egeci, I. S., \& Gencoz, T. (2011). The effects of attachment styles, problem-solving skills, and communication skills on relationship satisfaction. Procedia-Social and Behavioral Sciences, 30, 2324-2329.

Ellison, N. B. (2007). Social network sites: Definition, history, and scholarship. Journal of computer-mediated Communication, 13(1), 210-230. doi: 10.1111/j.10836101.2007.00393.x

Emery, L. F., Muise, A., Dix, E. L., \& Le, B. (2014). Can you tell that I'm in a relationship? Attachment and relationship visibility on Facebook. Personality and Social Psychology Bulletin, 40(11), 1466-1479. doi: 10.1177/0146167214549944

Finney, S. J., \& DiStefano, C. (2006). Non-normal and categorical data in structural equation modeling. In G. Hanchock \& R. Mueller (Eds.), Structural Equation Modeling: A second course (pp. 269-314). New York: Information Age Publishing, Inc.

Fox, J., \& Warber, K. M. (2013). Romantic relationship development in the age of Facebook: An exploratory study of emerging adults' perceptions, motives, and behaviors. Cyberpsychology, Behavior, and Social Networking, 16(1), 3-7. doi: 10.1089/cyber.2012.0288

Fox, J., Warber, K. M., \& Makstaller, D. C. (2013). The role of Facebook in romantic relationship development: An exploration of Knapp's relational stage model. Journal of Social and Personal Relationships, 30(6), 771-794. doi: $10.1177 / 0265407512468370$

Guerrero, L. K. (1998). Attachment-style differences in the experience and expression of romantic jealousy. Personal Relationships, 5(3), 273-291. doi: 10.1111/j.14756811.1998.tb00172.x

Hall, J. A. (2014). First comes social networking, then comes marriage? Characteristics of Americans married 2005-2012 who met through social networking sites. Cyberpsychology, behavior, and social networking, 17(5), 322-326. doi: 10.1089/cyber.2013.0408

Hand, M. M., Thomas, D., Buboltz, W. C., Deemer, E. D., \& Buyanjargal, M. (2013). Facebook and romantic relationships: Intimacy and couple satisfaction associated with online social network use. Cyberpsychology, Behavior, and Social Networking, 16(1), 8-13. doi: 10.1089/cyber.2012.0038

Joinson, A. N. (2008). Looking at, looking up or keeping up with people?: motives and use of facebook. In Proceedings of the SIGCHI conference on Human Factors in Computing Systems (pp. 1027-1036). ACM. doi: 10.1145/1357054.1357213

Kalpidou, M., Costin, D., \& Morris, J. (2011). The relationship between Facebook and the well-being of undergraduate college students. CyberPsychology, behavior, and social networking, 14(4), 183-189. doi: 10.1089/cyber.2010.0061 
Kamenov, Ž. \& Jelić, M. (2003). Validacija instrumenta za mjerenje privrženosti u različitim vrstama bliskih odnosa: Modifikacija Brennanova Inventara iskustava u bliskim vezama. [Validation of adult attachment measure in various types of close relationships: Modification of Brennan's Experiences in Close Relationship Inventory] Suvremena psihologija, 6, 73-91.

Kearns, J. N., \& Leonard, K. E. (2004). Social networks, structural interdependence, and marital quality over the transition to marriage: A prospective analysis. Journal of Family Psychology, 18(2), 383.

Kendrick, H. M., \& Drentea, P. (2016). Marital adjustment. Encyclopedia of Family Studies, 1-2.

Kirkpatrick, L. A., \& Davis, K. E. (1994). Attachment style, gender, and relationship stability: A longitudinal analysis. Journal of personality and social psychology, 66(3), 502-512. doi: 10.1037/0022-3514.66.3.502

Kujath, C. L. (2011). Facebook and MySpace: Complement or substitute for face-to-face interaction?. Cyberpsychology, Behavior, and Social Networking, 14(1-2), 75-78. doi: 10.1089/cyber.2009.0311

Ledbetter, A. M., Mazer, J. P., DeGroot, J. M., Meyer, K. R., Mao, Y., \& Swafford, B. (2011). Attitudes toward online social connection and self-disclosure as predictors of Facebook communication and relational closeness. Communication Research, 38(1), 27-53. doi: 10.1177/0093650210365537

Lewis, R. A., \& Spanier, G. B. (1979). Theorizing About the Quality and Stability of Marriage. S. 268-294 in: WR Burr/R. Hill/FI Nye/IL Reiss (Hrsg.): Contemporary Theories About the Family. General Theories/Theoretical Orientations.

Marshall, T. C., Bejanyan, K., Di Castro, G., \& Lee, R. A. (2013). Attachment styles as predictors of Facebook-related jealousy and surveillance in romantic relationships. Personal Relationships, 20(1), 1-22. doi: 10.1111/j.14756811.2011.01393.x

Meeks, B. S., Hendrick, S. S., \& Hendrick, C. (1998). Communication, love and relationship satisfaction. Journal of Social and Personal Relationships, 15(6), 755-773.

Milardo, R. M. (1986). Personal choice and social constraint in close relationships: Applications of network analysis. In Friendship and social interaction (pp. 145-166). Springer, New York, NY.

Muise, A., Christofides, E., \& Desmarais, S. (2009). More information than you ever wanted: Does Facebook bring out the green-eyed monster of jealousy? CyberPsychology \& behavior, 12(4), 441-444. doi: 10.1089/cpb.2008.0263

Muise, A., Christofides, E., \& Desmarais, S. (2014). "Creeping" or just information seeking? Gender differences in partner monitoring in response to jealousy on Facebook. Personal Relationships, 21(1), 35-50. doi: 10.1111/pere.12014

Nielsen, J. (2011). State of the media: the social media report. Nielsen Company. http://blog. nielsen. com/nielsenwire/social.

Overall, N. C., Fletcher, G. J., Simpson, J. A., \& Sibley, C. G. (2009). Regulating partners in intimate relationships: The costs and benefits of different communication strategies. Journal of personality and social psychology, 96(3), 620 .

Papp, L. M., Danielewicz, J., \& Cayemberg, C. (2012). “Are we Facebook official?” Implications of dating partners' Facebook use and profiles for intimate relationship satisfaction. Cyberpsychology, Behavior, and Social Networking, 15(2), 85-90. doi: 10.1089/cyber.2011.0291

Park, N., Kee, K. F., \& Valenzuela, S. (2009). Being immersed in social networking environment: Facebook groups, uses and gratifications, and social outcomes. CyberPsychology \& Behavior, 12(6), 729-733. doi: 10.1089/cpb.2009.0003 
Rus, H. M., \& Tiemensma, J. (2017). "It's complicated." A systematic review of associations between social network site use and romantic relationships. Computers in Human Behavior, 75, 684-703. doi: 10.1016/j.chb.2017.06.004

Smith, A., \& Duggan, M. (2013). Online dating \& relationships. Pew Internet \& American Life Project. http://pewinternet.org/Reports/2013/Online-Dating.aspx.

Spanier, G. B. (1976). Measuring dyadic adjustment: New scales for assessing the quality of marriage and similar dyads. Journal of Marriage and the Family, 2, 15-28. doi: $10.2307 / 350547$

Spanier, G. B. (1989). Manual for the Dyadic Adjustment Scale. North Tonowanda, New York: Multi-Health Systems.

Spanier, G. B., \& Lewis, R. A. (1980). Marital quality: A review of the seventies. Journal of Marriage and the Family, 825-839.

Sternberg, R. J. (1986). A triangular theory of love. Psychological review, 93(2), 119.

Surra, C. A. (1988). The influence of the interactive network on developing relationships. In R. M. Milardo (Ed.), Families and social networks (pp. 4881). Newbury Park, CA: Sage.

Tadinac, M., Kamenov, Z., Jelic M., i Hromatko, I. (2007). Što ljubavnu vezu čini uspješnom? [What makes an intimate relationship successful?] Izvještaj s XV Ljetnje psihologijske škole. Zagreb, Croatia: FF Press.

Thibaut, J.W., \& Kelley, H.H. (1959). The social psychology of groups. Oxford, England: John Wiley.

Tokunaga, R. S. (2011). Social networking site or social surveillance site? Understanding the use of interpersonal electronic surveillance in romantic relationships. Computers in Human Behavior, 27(2), 705-713. doi: 10.1016/j.chb.2010.08.014

Tucker, J. R. (2014). "It's Complicated: The Role of Facebook in Romantic Relationships Concerning Relational Certainty, Attachment, and Self-Esteem". Dissertations and Theses. Paper 1983. doi: 10.15760/etd.1982

Turkle, S. (2011). Alone Together: why we expect more from technology and less from ourselves. New York: Basic Books.

Young, S., Dutta, D., \& Dommety, G. (2009). Extrapolating psychological insights from Facebook profiles: A study of religion and relationship status. CyberPsychology \& Behavior, 12(3), 347-350. doi: 10.1089/cpb.2008.0165

Watson, D., Hubbard, B., \& Wiese, D. (2000). General traits of personality and affectivity as predictors of satisfaction in intimate relationships: Evidence from self-and partner-ratings. Journal of personality, 68(3), 413-449.

\section{ПОВЕЗАНОСТ ПОНАШАЊА НА ФЕЈСБУКУ И КАРАКТЕРИСТИКА ПАРТНЕРСКОГ ОДНОСА}

Ивана Исаиловић, Јелена Шакотић-Курбалија

Универзитет у Новом Саду, Филозофски факултет, Одсек за психологију, Нови Сад, Србија

\section{Резиме}

Појава друштвених мрежа значајно је променила услове и начин комуникације у XXI веку, па и у партнерским односима (Rus \& Tiemensma, 2017). Истраживачки налази говоре да сајтови за друштвено умрежавање играју значајну улогу у свим стадијумима развоја романтичних односа, укључујући упознавање, почетак везе, 
развој, одржавање, раскид, па чак и надзирање понашања бившег партнера (Smith \& Duggan, 2013).

Циљ овог истраживања био је да се утврди однос између начина коришћења Фејсбука (као једног од најпопуларнијих сајтова за друштвено умрежавање) и квалитета партнерског односа. На основу резултата претходних студија (Park, Kee, \& Valenzuela, 2009; Papp, Danielewicz, \& Cayemberg, 2012), претпоставили смо постојање значајних полних разлика у учесталости и начину коришћења услуга Фејсбука. Такође, претпоставили смо да стил афективне везаности игра значајну улогу у степену надзирања партнеровог понашања на Фејсбуку и у учесталости и интензитету конфликата везаних за начин коришћења Фејсбука. Најзад, претпоставили смо да се квалитет везе може предвидети на основу степена надзирања партнера на Фејсбуку и конфликата везаних за Фејсбук.

Резултати су потврдили претпоставку да жене чешће него мушкарци користе Фејсбук, постављају јавни статус везе и објављују профилне слике са партнером, што је у складу са резултатима претходних истраживања (нпр. Park, Kee, \& Valenzuela, 2009). Са друге стране, нису потврђене претпоставке да је чешће коришћење Фејсбука повезано са слабијим квалитетом везе и да су несигурно везане особе склоније да чешће објављују статус везе и профилне фотографије са партнером. Ови резултати су у нескладу са налазима претходних студија који сугеришу да се несигурно везане особе на друштвеним мрежама труде да јавно истакну своју повезаност са романтичним партнером због појачане потребе за блискошћу и страха од напуштања (Fox \& Warber, 2013; Marshall et al., 2013; Muise, Christofides, \& Desmarais, 2014). Резултати су потврдили претпоставку да су особе са несигурним стилом везаности склоније да надзиру понашање свога партнера на Фејсбуку, што је у складу са налазима претходних истраживања (Fox \& Warber, 2013; Marshall et al., 2013; Muise, Christofides \& Desmarais, 2014). Међутим, није потврђена хипотеза о постојању значајних разлика у постојању конфликата везаних за употребу Фејсбука међу особама са сигурним и несигурним обрасцима афективне везаности.

Последња истраживачка хипотеза односила се на постојање значајних веза између стила афективне везаности, конфликата везаних за употребу Фејсбука, надзирања партнеровог понашања на Фејсбуку и квалитета везе. Тачније, очекивали смо да су на подузорку несигурно везаних испитаника и конфликти везани за употребу Фејсбука и степен надзирања партнеровог понашања на Фејсбуку значајни показатељи квалитета везе, док је међу сигурно везаним испитаницима значајан показатељ квалитета везе само постојање несугласица и конфликата везаних за коришћење Фејсбука (нпр. неслагање око коментара које један од партнера оставља на профилима својих пријатеља и сл.). Резултати показују да је у обе групе испитаника само постојање конфликата везаних за употребу Фејсбука значајан показатељ квалитета везе, док се степен надзирања партнеровог понашања на друштвеним мрежама није показао као значајан показатељ квалитета везе ни код сигурно, а ни код несигурно везаних испитаника.

Ова студија је једна од првих у Србији која се бави повезаношћу активности на Фејсбуку са квалитетом романтичне везе, те, и поред одређених методолошких ограничења наведених у раду, указивањем на могуће факторе ризика који су последица коришћења Фејсбука, доприноси бољем разумевању динамике партнерских односа. 